DOI: $10.17516 / 1997-1370-0652$

УДК 101

\title{
Introduction to the Philosophical Thematic Issue of the Journal of Siberian Federal University
}

\author{
Natalia P. Koptseva* \\ Siberian Federal University \\ Krasnoyarsk, Russian Federation
}

Received 06.04.2020, received in revised form 04.08.2020, accepted 12.08.2020

\begin{abstract}
The introduction to the thematic issue devoted to philosophical sciences reveals the concept that unites all the articles published therein. Philosophical topics are developed by Russian scientists in different cities, scientific organisations and universities. One of the most famous in the modern philosophical world is the Institute of Philosophy of the Russian Academy of Sciences. The thematic philosophical issue contains articles by authors from this famous philosophical institute. However, not only Moscow School is presented in this issue, but no less famous St. Petersburg and Ural Schools of Philosophy also have their scientific representatives. Krasnoyarsk philosophers are represented by works related to philosophical methodology and historical and philosophical perceptions in modern culture. At present, Russian humanities refer to philosophy as a metatheory that provides the most effective methodological and conceptual approaches not only for the social sciences and humanities, but also for modern natural science and technological discoveries.
\end{abstract}

Keywords: philosophy, history of philosophy, methodology, concepts, schools of philosophy.

Research areas: philosophy; culturology.

Citation: Koptseva, N.P. (2020). Introduction to the philosophical thematic issue of the Journal of Siberian Federal University. J. Sib. Fed. Univ. Humanit. Soc. Sci., 13(8), 1234-1237. DOI: 10.17516/1997-13700652 .

\footnotetext{
(C) Siberian Federal University. All rights reserved

* Corresponding author E-mail address: decanka@mail.ru ORCID: 0000-0003-3910-7991
} 
Philosophical sciences in the modern world retain their importance in various aspects. From the point of view of natural science, technical sciences, humanities and social research, philosophical sciences develop conceptual and methodological approaches, substantiate concepts, categories, principles, and study the patterns of intellectual activity and thinking. At the same time, philosophy reflects on its own basis, transforming into metaphilosophy (Vasil'ev, 2019, Oizerman, 2009, Porus, 2019, Safonov, 2018). The history of philosophy also acts as a metaphilosophy (Oizerman, 2009, Koptseva, 2017), since here philosophical reflection is placed in the temporal context and embedded in the historical logic of various forms of culture (Koptseva \& Kirko, 2014).

Modern philosophical sciences continue to serve as the basis for the emergence of new forms of humanitarian and social knowledge: studies of cultural memory, media research, educational sciences (Kurennoy, 2020a, 2020b), gender studies, ethnic studies and religious studies are connected in different ways with philosophical range of issues that do not arise in the $21^{\text {st }}$ century, but originate from the first ancient schools, where philosophy first acquired a name, form, status and content.

In the thematic philosophical issue of the Journal of Siberian Federal University, an attempt is made to cover various forms of the modern existence of philosophy. First of all, we are talking about the established schools of philosophy, the mother of which is the School of Philosophy associated with Lomonosov Moscow State University and the Institute of Philosophy of the Russian Academy of Sciences. Thus, the first deans of the Department of Philosophy at Ural University were professors of Lomonosov Moscow State University - Leonid Mikhailovich Arkhangelsky and Mikhail Nikolaevich Rutkevich.

No less famous and highly effective is St. Petersburg School of Philosophy, closely associated with Krasnoyarsk philosophical community. Thus, the first dean of the Department of History and Philosophy at Krasnoyarsk University and the founder of the Department of Philosophy at this university, Albert Yanovich Raibekas, was a graduate of the Leningrad
State University majoring in two fields: physics and philosophy. This is a very representative situation for the $50 \mathrm{~s}$ of the $20^{\text {th }}$ century, when scientific and technological progress was inseparable from philosophical understanding, and Soviet philosophy was consciously developing as the philosophy of modern science and technology.

Since ancient times, philosophy has accompanied itself with the reflection of its own foundations, including those built in a certain historical logic. The history of philosophy is always associated with the current status of philosophy, which shows that modern civilizational problems can find a good solution in ancient wisdom, in the arguments of Plato and Aristotle, their students, which constitutes the school of world philosophy.

In the proposed thematic philosophical issue, a benevolent reader will find various philosophical topics, get acquainted with new authors, learn the results of new research by authors that are well known today in Russia and the world. The core of the thematic issue is constituted by articles by the Institute of Philosophy of the Russian Academy of Sciences, this scientific organisation is represented here by 7 author's in-depth studies, reflecting the tendencies of modern Russian philosophy. We are talking about the articles by the Member of the Russian Academy of Sciences A.A. Guseinov, Corresponding Member of the Russian Academy of Sciences Yu.V. Sineokaya, Doctor of Philosophy V.K. Shokhin, Doctor of Philosophy A.V. Prokofyev, Doctor of Philosophy A.Yu. Antonovskiy, Junior Researcher S.Yu. Boroday. For this module of scientific articles, the Member of the Russian Academy of Sciences A.V. Smirnov and RAS Corresponding Member Yu.V. Sineokaya were invited editors. The Editorial Board of the Journal expresses its sincere gratitude to them and expresses hope for further fruitful cooperation.

Two articles by authors from St. Petersburg - Roman Viktorovich Svetlov and Elena Vladimirovna - to a certain degree represent the philosophical studies of this university city, the second philosophical capital of our country, the connection of which with Krasnoyarsk philosophers was mentioned above. 
The Ural School of Philosophy sent many students to Krasnoyarsk University in the first half of the $80 \mathrm{~s}$ of the $20^{\text {th }}$ century. Therefore, the publication of Ural authors, I. Krasavin and T. Kerimov, can naturally be supplemented by the article by V. Zhukovsky and D. Pivovarov. Professor V.I. Zhukovsky is a student of Professor D.V. Pivovarov. Daniil Valentinovich Pivovarov stood at the origins of our scientific journal. He left us early and with the publication of his article the Editorial Board wants to once again honour his memory and express its gratitude to him for his constant intellectual assistance. The theory of culture as a process of ideal formation is the main conceptual and methodological principle of Krasnoyarsk research in the field of culture studies, art history, religious studies, ethnology, social and cultural anthropology. Thus, the philosophical school goes beyond the boundaries of a region or city and, through its students, settles in other regions and cities, contributing to the expansion of the Republic of scientists (F. Bacon).

Thus, Professor V.I. Zhukovsky already represents Krasnoyarsk school, which the re- search of Professor N.P. Koptseva in collaboration with Associate Professor K.V. Reznikova on contemporary historical and philosophical topics is adjacent. In the article by N.P. Koptseva and K.V. Reznikova philosophy reveals its methodological function for ancient natural science, which is the basis of various modern sciences.

Regional philosophical schools are not limited to Yekaterinburg, but are logically supplemented by the city of Orenburg, whose authors - Doctor of Philosophy I. Belyaev and Candidate of Philosophy M. Lyashchenko presented the Journal with the results of their philosophical studies of socio-cultural determinants of current Russian processes.

Thus, philosophical research on the banks of the Yenisei continues by means of effective interaction and modern scientific communication. The Editorial Board welcomes its new authors and expresses the hope that new times will bring new opportunities and modern Russian philosophy will be presented in the Humanities Series of the Scientific Journal of Siberian Federal University through various trends and philosophical styles.

\section{References}

Koptseva, N.P., \& Kirko, V.I. (2014). Some concepts of late nineteenth and early twentieth-century Russian philosophy, revealing specific forms of collective identities. In Revista de Filosofia, 76(1), 7-31.

Koptseva, N.P. (2017). Truth in Martin Heidegger's fundamental ontology. In Revista de Filosofia, 85(1), 22-45.

Kurennoy, V.A. (2020a). Filosofiia liberal'nogo obrazovaniia: printsipy [Philosophy of liberal education: principles]. In Voprosy obrazovaniia [Issues of Education], 1, 8-39.

Kurennoy, V.A. (2020b). Filosofiia liberal'nogo obrazovaniia:konteksty [Philosophy of liberal education: contexts]. In Voprosy obrazovaniia [Issues of Education], 2, 8-36.

Oizerman, T.I. (2009). Metafilosofia. Teoriia istoriko-filosofskogo protsessa [Metaphilosophy. Theory of historical and philosophical process], Moscow, Institute of Philosophy of the Russian Academy of Sciences.

Porus, V.N. (2019). Filosofskii status "Metafilosofii nauki” [Philosophical status of "Metaphilosophy of science"]. In Epistemologiia i filosofiia nauki [Epistemology and philosophy of science], 2 (56), 134-150.

Safonov, A.S. (2018). Filosofiia v meniaiushchemsia mire: tri tipa metafilosofii [Philosophy in the changing world: three types of metaphilosophy]. In SocioTime, 4(16), 27-35. DOI: 10.15350/2410-0773.2018.4.27

Vasil'ev, V.V. (2019). Metafilosofiia: istoriia i perspektivy [Metaphilosophy: history and prospects]. In Epistemologiia i filosofiia nauki [Epistemology and philosophy of science, 2 (56), 6-18. 


\title{
Вступительная статья к философскому \\ тематическому выпуску журнала \\ Сибирского федерального университета \\ «Гуманитарные науки»
}

\section{Н.П. Копцева}

Сибирский федеральный университет

Российская Федераџия, Красноярск

\begin{abstract}
Аннотация. Во введении к тематическому номеру, посвященному философским наукам, раскрывается замысел, объединяющий все статьи, опубликованные в нем. Философская тематика разрабатывается российскими учеными в разных городах, научных организациях, университетах. Разумеется, одним из наиболее известных в современном философском мире является Институт философии Российской академии наук. В основу тематического философского номера были положены статьи авторов, работающих в этом знаменитом философском институте. Однако не только московская школа представлена в данном номере, не менее знаменитые санкт-петербургская, уральская философские школы также имеют своих научных репрезентантов. Красноярские философы представлены работами, связанными с философской методологией и историко-философскими рецепциями в современной культуре. В настоящее время российская гуманитаристика обращается к философии как метатеории, дающей наиболее эффективные методологические и концептуальные подходы не только для социальных и гуманитарных наук, но и для современного естествознания и технологических открытий.
\end{abstract}

Ключевые слова: философия, история философии, методология, концепции, философские школы.

Научные специальности: 09.00.00 - философские науки; 24.00.00 - культурология. 